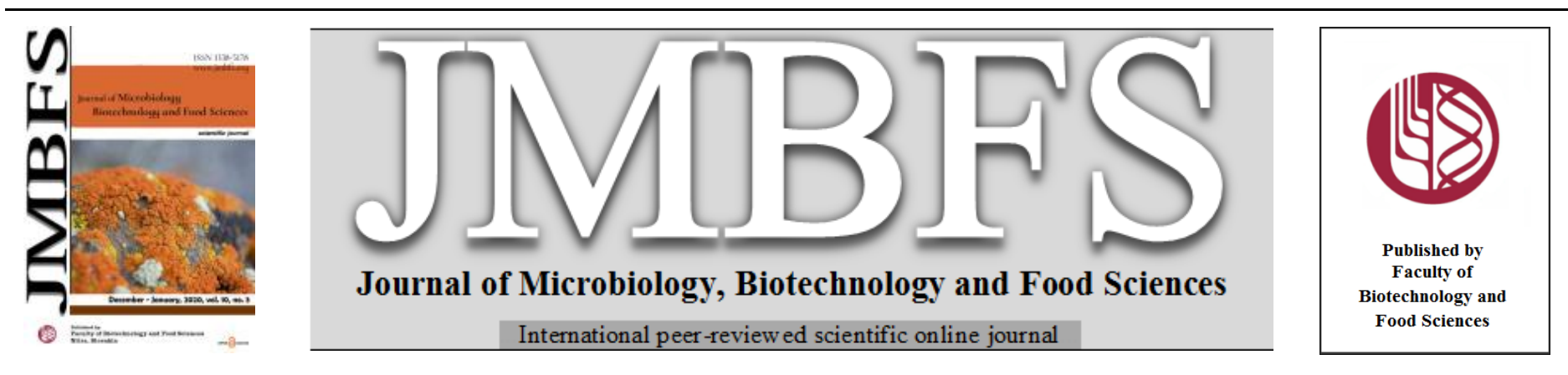

\title{
ISOLATION AND IDENTIFICATION OF RHIZOBACTERIA FROM MAIZE (ZEA MAYS L.) IN LUVISOLS AND DOCUMENTATION THEIR PLANT GROWTH PROMOTING TRAITS
}

\author{
Soňa Javoreková*, Renata Cinkocki, Jana Maková, Nikola Hricáková
}

Address(es): prof. Ing. Soňa Javoreková, $\mathrm{PhD}$.

Department of Microbiology, Faculty of Biotechnology and Food Sciences, Slovak University of Agriculture in Nitra, Trieda Andreja Hlinku 2, 94976 Nitra, Slovakia.

*Corresponding author: sona.javorekova@uniag.sk

doi: $10.15414 / j m b f s .2020 .10 .3 .505-510$

ARTICLE INFO

Received 18. 9. 2020

Revised 8. 10. 2020

Accepted 18. 11. 2020

Published 1. 12. 2020

$\underline{\text { Regular article }}$

open $\partial_{\text {ACCESS }}$

\begin{abstract}
There is a growing interest in the issue of inoculation of rhizobacteria into the agricultural soil because this group of bacteria can increase productivity and quality of agriculturally important crops and contributes to the stability of agroecosystems. The aim of our work was to isolate and characterize of plant growth promoting traits (production of IAA, siderophores, phosphate solubilisation, antifungal activity) of rhizobacteria belonging to a group of plant growth promoting rhizobacteria (PGPR), from rhizosphere of maize (Zea mays L.) in luvisols. Quantitative representation of rhizobacteria of maize rhizosphere was $7.4 .10^{6} \mathrm{CFU} \cdot \mathrm{g}^{-1} \mathrm{dry}$ soil. A total of eleven species of maize rhizosphere where isolated and confirmed as PGPR in vitro. The all isolates showed positive indole-3-acetic acid (IAA) production ranging between 1.39 and $15.74 \mu \mathrm{g} \cdot \mathrm{ml}^{-1}$. Seven strains $(63.6 \%)$ has been shown with low and 1 strain with intermediate solubilisation index of phosphates and the positive production of siderophores showed 7 isolates $(63,6 \%)$. Except for the isolate KmiJP17B089, all others inhibited the growth of Sclerotinia sclerotiorum and Rhizoctonia solani by more than $50 \%$. In the case of Fusarium graminearum, on the other hand, we observed a very low inhibitory activity. Three isolates which were the most active in observed traits were identified by the 16S rRNA gene sequencing and by BLAST alignment of NCBI database as Bacillus altitudinis strain KmiJP17B089, Bacillus aryabhattai strain KmiJP17B090 and Bacillus megaterium strain KmiJP17B091. These results suggest the possibility of in vitro testing of these Bacillus species as potential biological fertilizer to increase maize production.
\end{abstract}

Keywords: rhizobacteria, indole-3-acetic acid, siderophores, phosphate solubilization, antifungal activity, Zea mays L., Bacillus sp. luvisols

\section{INTRODUCTION}

Hiltner (1904) discovered that the rhizosphere is the layer of soil influenced by the root, and is much richer in bacteria than the surrounding bulk soil. The plant rhizosphere is determined by the synergistic relationship between the soil, plant root, and the microbes present and is influenced by the soil $\mathrm{pH}$, texture, complexity and plant roots exudates mainly composed of sugars, amino acids and different nutrients (Mendes $\boldsymbol{e t}$ al., 2013). The rhizosphere can be defined as a zone of soil that surrounds the plant root, is a hot spot for numerous organisms and is considered as one of the most complex ecosystem on Earth (Raaijmakers et al., 2009). Plant growth promoting rhizobacteria are free-living soil bacteria that colonize the rhizosphere area of root and improve the ability of nutrients and in a variety of modes of action such as the production of phytohormones, phosphate solubilization and siderophore production or supression the phytopathogenic fungi (Grobelak et al., 2015). Many bacterial genera such as Pseudomonas, Bacillus, Enterobacter, Rhizobium, Bradyrhizobium, and Xanthomonas have been reported as potential phytohormones producing rhizobacteria (Asari et al., 2016) to support plant growth.

Maize (Zea mays L.) is the second most abundantly produced cereal in the world and one of the oldest crops. Inoculation of maize with various PGPR strains, however could result in significant increases in plant biomass, root and shoot length and uptake of essential plant nutrients. The use of plant growth-promoting rhizobacteria (PGPR) is a promising alternative method to external chemical inputs to improve crop yield in sustainable agricultural systems (Yadav et al., 2017).

The aim of our study was isolation, characterization and identification of the most active rhizobacteria from maize and in vitro testing of their PGPR traits (phosphate solubilization, production of IAA, production of siderophores and antifungal activity) for potential in enhancing the growth of a maize crop.

\section{MATERIAL AND METHODS}

\section{Sampling characteristics and isolation of bacterial isolates}

Bacteria were isolated from the rhizosphere of maize that grown on the altitude of $199 \mathrm{~m}$ above sea level in University farm in the Slovak University of Agriculture (SUA) in Kolínany $\left(48^{\circ} 21^{\prime} 33^{\prime \prime} \mathrm{N}, 18^{\circ} 11^{\prime} 28^{\prime \prime} \mathrm{E}\right)$. According to FAO classification, the experiment was conducted on the luvisols (Chromic Luvisols). The soil type from the experimental field Kolínany was haplic luvisols with low to medium humus content $(1.91 \%)$, very low total nitrogen content $(0.19 \%)$ and neutral $\mathrm{pH} / \mathrm{H}_{2} \mathrm{O}$ (7.32) soil reaction. Genotype KESSOS is a two-liner hybrid of maize, designed for grain, very well resistant to dry stress, evenly ripening with moderate initial growth. Samples (50 grams each) were collected from the upper $5 \mathrm{~cm}$ layer of the rhizosphere from 6 randomly roots of the plant in the phenological growth phase 15 (BBCH 15).

The quantification and isolation of rhizobacteria to pure culture was conducted following a standard microbiological procedure using the serial dilution of agar plate methods on Triptone soya agar (TSA) (Himedia Laboratories, India). The plates were prepared on three replicates and incubated at $28 \pm 2^{\circ} \mathrm{C}$, for $48 \mathrm{~h}$. It is shown in colony-forming units (CFU) per g of dry soil. Subsequently, individual colonies were picked and streaked on Cetrimide agar (Himedia Laboratories, India) and Pikovskaya's agar (Himedia Laboratories, India) plates for further purification and test PGPR traits (phosphate solubilization, production of IAA, production of siderophores and antifungal activity). In soil were observed active $\mathrm{pH}$ in $\mathrm{H}_{2} \mathrm{O}$, the total nitrogen content $(\mathrm{Nt})$ by Kjeldahl method, and the total carbon content (Cox) by Tjurin method.

\section{Phosphate solubilization}

Bacterial phosphate solubilization ability was determined qualitatively on Pikovskya's (PVK) medium with 0,4\% bromophenol blue solution (Gupta et al.., 1994). The plates were incubated at $28 \pm 2{ }^{\circ} \mathrm{C}$ for $7-10$ days and observed for the formation of a clear halo zone around the bacterial colonies, were considered 
phosphate solubilizers. All assays were performed in triplicate and mean was calculated from halo diameter and colony diameter in millimeters (mm). From these measurements the Solubilisation index (SI) of phosphates was calculated determined by Berraquero et al. (1976) as the ratio of diameter of the bacteria colonies + halozone / diameter of the bacterial colonies. The all measurements were performed using a IUL Haloes digital caliper. Based on the solubilisation index, strains were classified according to Marra et al. (2011) as low (SI < $2.00)$, intermediate $(2.00 \leq \mathrm{SI}<4.00)$ or high $(\mathrm{SI} \geq 4.00)$ for their ability to solubilise.

\section{Production of Indole-3-acetic acid (IAA)}

Bacterial cultures were grown in Pikovskaya's medium with tryptophane (100 $\mu \mathrm{g}$ . $\mathrm{ml}^{-1}$ ) and incubated at $28 \pm 2{ }^{\circ} \mathrm{C}$ for 7 days. IAA production was determined using a colorimetric method (Gordon and Weber, 1951) with Salkowski's reagent. Development of pink colour indicated IAA production, and the absorbance of the solutions were observed at $530 \mathrm{~nm}$. IAA-like auxins were expressed as milligram per liter over uninoculated control. The experiment was three replicates and mean was calculated.

\section{Production of siderophores}

Siderophore production was detected using Chrome Azurol Sulphonate (CAS) agar plates qualitatively according to Schwyn and Neilands (1987). The plates were incubated at $30 \pm 2^{\circ} \mathrm{C}$ for $72 \mathrm{~h}$ and the ability of bacterial cultures was confirmed by the formation of orange or yellow zone around the bacterial colonies. The experiment was three replicates and mean was calculated.

\section{Antifungal activity}

Screening of bacterial culture to inhibit the growth of phytopathogenic fungi Fusarium graminearum KMi-16H006, Rhizoctonia solani KMi-003-JM and Sclerotinia sclerotiorum KMi-003-JM were performed in vitro. Phytopathogenic fungi was obtained from Collection of Microorganisms of Department of Microbiology Slovak University of Agricultural in Nitra, and incubated on the Potato Dextrose agar (PDA) at $25 \pm 2^{\circ} \mathrm{C}$ for 7 days. These genus were chosen because it has been proposed to have worldwide distribution as pathogenic agent and to cause considerable losses under field conditions. From bacterial cultures was prepared bacterial suspension in sterile ultrapure water and inoculated in the plates with PDA agar, into the centre of plates was placed mycelium of phytopathogenic fungi. The plates were incubated at $25 \pm 2{ }^{\circ} \mathrm{C}$ for 10 days. For the negative control, the same amount of sterile medium was not inoculated with bacterial suspension. The experiment was three replicates and mean was calculated. The inhibition of the growth of fungal mycelium was calculated according the Sgroy $\boldsymbol{e t}$ al. (2009). Mycelia growth inhibition was calculated as I $=(\mathrm{C}-\mathrm{T} / \mathrm{C}) \times 100$, where $\mathrm{I}=$ mycelia growth inhibition in percentage, $\mathrm{C}=$ mycelia diameter in control, and $\mathrm{T}=$ mycelia diameter in bacteria-inoculated plates. Subsequently, we evaluated the antifungal activity as +++ strong inhibition $(>80 \%),++$ moderate inhibition $(80-40 \%),+$ low inhibition $(<40$ $\%)$.

\section{Characterization and identification of PGPR strains}

Morphological, growth and biochemical studies of viable colonies of PGPR were performed using standard methods in soil microbiology (Alef and Nannipieri, 1995). Gram staining, sporulation, growth of anaerobic, acid from glucose, mobility, oxidase, catalase were used for characterization of the all 11 isolates of PGPR.

Strains for genetic analysis were inoculated on Triptone soya agar and incubated at $28 \pm 2{ }^{\circ} \mathrm{C}$. DNA was extracted from 24 hours old bacterial culture Approximately $50 \mathrm{mg}$ of bacterial culture was placed in $200 \mu \mathrm{l}$ of PrepMan solution (Life technologies) and homogenized with glass beads on BeadBug homogenizer (Benchmark scientific). DNA sequences of 16S rRNA gene were amplified by using the universal primers. The forward primer $27 \mathrm{~F}\left(5^{\prime}\right.$ AGAGTTTGATCCTGGCTCAG-3') and reverse primer 1492R (5'TACGGTTACCTTGTTACGACTT-3') were used (Lane et al., 1991). Thirty $\mu 1$ of PCR mixture contained $3 \mu 1$ 10X Dream Taq DNA buffer, $3 \mu 1$ of $2 \mathrm{mM}$ dNTP mix, $1 \mu \mathrm{l}$ of $\mathrm{MgCl}_{2}, 1.2 \mu \mathrm{l}$ each of the opposing amplification primers (10 $\mathrm{mM}), 0.1 \mu \mathrm{l}$ Dream Taq DNA polymerase and $1 \mu$ l of genomic DNA. PCR amplification was performed in thermocycler MJ Mini (Biorad, USA). The amplification reaction was performed in a thermal-cycler (Eppendorf thermocycler) programmed for an initial cycle of $95^{\circ} \mathrm{C}$ for $3 \mathrm{~min}$, followed by 40 cycles of $95{ }^{\circ} \mathrm{C}$ for $30 \mathrm{~s}, 56{ }^{\circ} \mathrm{C}$ for $30 \mathrm{~s}, 72{ }^{\circ} \mathrm{C}$ for $90 \mathrm{sec}$, followed by a final extension at $72{ }^{\circ} \mathrm{C}$ for $10 \mathrm{~min}$. PCR - amplified 16S rDNA was purified by enzymatic treatment and sequenced in MacroGen Company, South Korea. The similarity and homology of the 16S rRNA partial gene sequences was compared with available sequences by the BLAST algorithm (Saitou and Nei, 1987) in the NCBI (National Centre for Biotechnology Information) database (http://www.ncbi.nlm.nih.gov). The DNA sequences were aligned and phylogenetic tree was constructed by PhyML software using Maximum like hood tree. A bootstrap analysis of 1000 replicates was carried out using Molecular Evolutionary Genetics Analysis (MEGA) 6.06 (Tamura et al., 2011).

\section{RESLUTS AND DISCUSSION}

\section{Quantity of rhizobacteria}

Quantitative representation of bacteria in the rhizosphere of maize was 7.4. $10^{6}$ CFU.g ${ }^{-1}$ of dry soil. Despite the fact that important factors influencing the numerous abundance of microorganisms in the soil include in particular the plant species and the soil type, the determined numbers of rhizobacteria were of the order of $\left(10^{6}\right)$ comparable to the numbers of rhizobacteria isolated e.g. from the rhizosphere of wheat (Melnichuk et al., 2019) from black soil in the Crimea, or maize in the tropical soils of West Africa (Agbodjato et al., 2015). The numbers of rhizobacteria isolated from chernozem maize in Novi Sad, Serbia, were twice as high (Mrkovački et al., 2016). However, this could be due to high doses of $250 \mathrm{~kg}$ NPK . ha ${ }^{-1}$ in autumn and $140 \mathrm{~kg}$ urea . ha ${ }^{-1}$ in the spring. Fertilization of agricultural soils increases the proportion of bacteria that have a significant antagonistic relationship to phytopathogens (Charousová et al., 2016; Halenárová et al., 2016; Javoreková et al., 2019). The determined low values of humus and nitrogen content in the tested soil, but for most microorganisms an acceptable neutral $\mathrm{pH}$, also give rise to a significantly higher number of rhizobacteria after the application of the fertilizer.

\section{Plant growth promoting traits of isolates}

The all tested isolates (Table 1) based on the determined plant growth promoting traits supporting properties proved in at least one of them that we can call them PGPR. Based on these results we selected the 3 most active isolates for the next morphological, biochemical and genotypic characterization.

Table 1 Bacterial isolates and their PGPR traits

\begin{tabular}{|c|c|c|c|c|c|c|}
\hline \multirow{2}{*}{ Strain } & \multirow{2}{*}{ SI } & \multirow{2}{*}{$\underset{\left[\mathrm{mg}^{2} \mathrm{~L}^{-1}\right]}{\text { IAA }}$} & \multirow{2}{*}{$\begin{array}{l}\text { Sidero- } \\
\text { phores }\end{array}$} & \multicolumn{3}{|c|}{ Antifungal activity [\%] } \\
\hline & & & & Fusarium & Rhizoctonia solani & Sclerotinia \\
\hline KmiJP17B085 & 1.9 & 3.65 & NP & $0(+)$ & $78.83(++)$ & $100.00(+++)$ \\
\hline KmiJP17B086 & 0 & 2.83 & $\mathrm{NP}$ & $71.43(++)$ & $100(+++)$ & $100.00(+++)$ \\
\hline KmiJP17B087 & 1.82 & 1.39 & PP & $35.71(+)$ & $38.89(+)$ & $100.00(+++)$ \\
\hline KmiJP17B088 & 1.74 & 2.71 & PP & $14.43(+)$ & $72.22(++)$ & $100.00(+++)$ \\
\hline KmiJP17B089 & 1.29 & 15.74 & PP & $14.28(+)$ & $100(+++)$ & $4.44(+)$ \\
\hline KmiJP17B090 & 1.65 & 10.56 & $\mathrm{PP}$ & $27.14(+)$ & $100(+++)$ & $100.00(+++)$ \\
\hline KmiJP17B091 & 2.96 & 3.13 & $\mathrm{NP}$ & $20.72(+)$ & $77.78(++)$ & $100.00(+++)$ \\
\hline KmiJP17B092 & 0 & 1.65 & PP & $47.86(++)$ & $100(+++)$ & $74.44(11)$ \\
\hline KmiJP17B093 & $1, .8$ & 3.43 & $\mathrm{NP}$ & $41.43(++)$ & $100(+++)$ & $77.78(++)$ \\
\hline KmiJP17B094 & 1 & 2.58 & PP & $24.29(+)$ & $56.11(++)$ & $63.89(++)$ \\
\hline KmiJP17B095 & 0 & 4.08 & $\mathrm{PP}$ & $64.29(++)$ & $100(+++)$ & $100.00(+++)$ \\
\hline
\end{tabular}

SI - solubilization index of phosphate, IAA - indole-3-acetic acid, NP - no production, PP - positive production,
Antifungal activity: +++ strong inhibition $(>80 \%),++$ moderate inhibition $(80-40 \%),+$ low inhibition $(<40 \%)$.

\section{IAA production}

Indole-3-acetic acid (IAA) is the physiologically most potent auxin in plant growth and development (Vurukonda et al., 2016) and supported to enhanced lateral root branching and development of root hairs (Vacheron et al., 2013) According to the date in Table 1 , the all isolates $(100 \%)$ in our study produced of IAA, while Silini - Cherif et al. (2016) states that only $80 \%$ of the rhizosphere bacteria are capable of producing IAA. The amount of IAA produced by these 
isolates ranged from 1.39 to $15.74 \mu \mathrm{g} \cdot \mathrm{ml}^{-1}$ in Pikovskaya's broth with Ltryptophan as a precursor of IAA synthesis. The amino acids, especially tryptophan played a major role in the production of IAA by rhizobacteria (De La Torre-Ruiz et al., 2016). IAA production was comparable to the IAA values (0.5- $\left.5 \mu 1 . \mathrm{ml}^{-1}\right)$ reported by several authors (De La Torre-Ruiz et al., 2016; Karnwal, 2017) in the same tested dose of tryptophan $100 \mu \mathrm{g} \cdot \mathrm{ml}^{-1}$. Similarly, our results were in agreement with other research reports, $100 \mathrm{mg} \cdot \mathrm{ml}^{-1} \mathrm{~L}$ tryptophan in cultivation medium is suitable for IAA production by rhizospheric bacteria in vitro studies. Only two isolates KmiJP17B089 $\left(15.74 \mu \mathrm{g} \cdot \mathrm{ml}^{-1}\right)$ and KmiJP17B090 (10.56 $\left.\mu \mathrm{g} \cdot \mathrm{ml}^{-1}\right)$ produced relatively high levels of IAA According to Barazani and Friedmann (1999) value IAA above $13.5 \mu \mathrm{g} \cdot \mathrm{ml}^{-1}$ which confirms that it is considered PGPR. Strains that produce a large amount of IAA, and acetamide indole, in soil increase the growth and yield of crops. It has been reported that plants, under certain constraints, are dependent mainly on exogenous sources of phytohormones including those synthesized by bacteria. Root exudates are a natural source of L-tryptophan for microorganisms of the rhizosphere. In addition to the tryptophan dose, production is dependent on species, culture condition, growth phase and substrate availability (Silini - Cherif et al., 2016).

\section{Phosphate solubilisation}

Phosphorus is the second most important nutrient after nitrogen, required by plants for growth. In the environment, most phosphorus is available in an insoluble form that cannot be directly utilized by plants. Various soil bacteria are capable of solubilising mineral phosphates into a plant utilizable form that represents a possible mechanism of plant growth promotion (Ashrafuzzaman $\boldsymbol{e}$ al,. 2009). Of the 11 isolates evaluated for the solubilization of phosphates, eight $(72.7 \%)$ isolates showed a low solubilization index SI $(<2.00)$ and only 1 isolate KmiJPB091 $(2.96 \mathrm{~mm})$ showed medium solubilization index. Phosphate solubilization bacteria (PSB) can convert tricalcium phosphate in Pikovskaya's agar plates in medium from insoluble to soluble form. Kumar et al. (1999) isolated bacteria from rhizosphere of maize and $33 \%$ of bacterial isolates showed a medium solubilization index. Phosphate solubilization is mainly due to the production of microbial metabolites including organic acids which decreases the pH of the culture media (Puente et al., 2004; Shahid et al., 2012). The presence of P-solubilizing microbial population in soils may be considered a positive indicator of utilizing the microbes as biofertilizers for crop production and beneficial for sustainable agriculture. The application of these strains could prove to be highly beneficial in calcareous soils where phosphorus deficiency is attributed to the binding of phosphate with calcium (Kaur et al., 2018).

\section{Siderophore production}

Siderophores are low molecular weight iron-coordinating, organic compounds produced by most aerobic and facultative anaerobic microorganisms to combat low-iron stress (Neilands and Leong, 1986). The excretion of siderophores by rhizosphere bacteria may stimulate plant growth by improving Fe nutrition of the plants (Masalha et al., 2000) and protect the health of plants from several fungal or bacterial diseases. The majority of the isolated strains produced siderophores at highly variable rates (Silini - Cherif $\boldsymbol{e t}$ al., 2016). Of the 11 isolates evaluated in our study for the production of siderophores, 7 isolates $(63.6 \%)$ showed a positive test as indicated by the formation of an orange halo zone on CAS agar media (Table 1). If we used a liquid medium, the production of siderophores could be even higher (Tian et al., 2009). However, soil samples had favourable $\mathrm{pH}$ values, and according to Khan et al. (2018) in neutral and alkaline $\mathrm{pH}$ soils the production of siderophores is increased, because the iron solubility is reduced. The production of siderophore is mainly characteristic for gram negative bacteria, as a rule, only $1.7 \%$ of the total present are gram positive bacteria (Tian et al., 2009). However, in our case, all three identified isolates (Bacillus sp.) were gram positive (Table 2) and two of them confirmed the ability to produce siderophores (Table 1). Siderophores did not produce the isolate KmiJP17B091, identified as Bacillus megaterium, which may have been due to static conditions delayed and reduced the growth and the production of siderophore, compared with the incubation in stirred conditions (Santos et al., 2014). Only in the case of the KmiJP17B091 isolate identified as Bacillus megaterium have we not recorded the production of siderophores. Also according to Silini - Cherif et al. (2016) some species of Bacillus sp., caused to iron-limiting conditions. PGPR produces a range of siderophores that have a strong affinity for iron. Siderophore producing bacteria plays an important role in the biological control against certain phytopathogens. Bacteria produce siderophore and it is bind with the iron strongly and make it unavailable for the plant pathogens, therefore inhibiting the growth phytopathogens (Beneduzi et al., 2012). However, in our study we could not establish a relationship between siderophore production and antagonism to the plant pathogenic fungi (isolate KmiJP17B086) what may suggest that the detected antagonism probably was due to the synthesis of toxic compounds, such as antibiotics (Ribeiro et al., 2012).

\section{Antifungal activity}

Pathogenic microorganisms affect plant health and are a major threat to crop production. Many plant growth-promoting rhizobacteria (PGPR) residing in the rhizosphere of plants have been reported to enhance plant growth and inhibit plant pathogens by various mechanisms (Kaur et al., 2018). Maize is one of the crops that is attacked by a number of pests at all growth stages. Among the most common are microscopic fungi, especially representatives of the genus Fusarium. This was confirmed by our results, as we have recorded the lowest antifungal effect of PGPR isolates on Fusarium graminearum. For the other two fungi representatives tested, the inhibitory effect was greater than $60 \%$, but never reached $100 \%$. Our results confirmed good resistance of maize to Rhizoctonic solani and Sclerotinia sclerotiorum, which can be caused by precisely high efficiency $(100 \%)$ many PGPR against these pathogens. Similar results with low antifungal activity (max. $78 \%$ ) published Ali et al. (2020). Zhen et al. (2011) reported, that PGPR are able to inhibit the growth of mycelium of phytopathogenic fungi in vitro of the strains Rhizoctonia solani, Fusarium oxysporum, Fusarium solani, and Physalospora piricola. The inhibition rates against the different fungi ranged from 55.26 to 88.17 . \%. Of the 11 isolates tested for the antifungal activity of the three phythopathogens, 7 isolates $(63.6 \%)$ had more than $80 \%$ growth inhibition of Sclerotinia sclerotiorum, 6 isolates (54. $5 \%$ ) had more than $80 \%$ growth inhibition of Rhizoctonia solani. only 4 isolates had more than $40 \%$ growth inhibition of Fusarium solani. The highest antagonistic activity was shown by isolate KmiJP17B086 against all tested fungi (Table 2). Interestingly, this traits did not have arelated with the other PGPR traits studied, because it was this representative that was the lowest. Many PGPR which show good results in vitro fail to give the same results in the field, when applied as microbial inoculants due to the stress imposed by the sudden change in the environment (Praveen Kumar et al. 2014).

Table 2 Characterization of putative PGPR strain isolated from maize based on morphological, biochemical and sequencing of partial $16 \mathrm{~S}$ rDNA sequences and BLAST alignment

\begin{tabular}{|c|c|c|c|}
\hline Test & Bacillus altitudinis KmiJP17B089 & Bacillus aryabhattai KmiJP17B090 & Bacillus megaterium KmiJP17B091 \\
\hline \multicolumn{4}{|c|}{ Morphological and biochemical characteristics } \\
\hline Bacteria shape & Long rod & Long rod & Long rod \\
\hline Gram reaction & positive & positive & Positive \\
\hline Sporulation & + & + & + \\
\hline Colony colour & white & peach & white/cream \\
\hline Acid from glucose & + & + & + \\
\hline Mobility & + & + & + \\
\hline Oxidase & + & + & + \\
\hline Catalase & + & + & + \\
\hline Nitrate reduction & - & + & - \\
\hline \multicolumn{4}{|c|}{ Genetic characteristics } \\
\hline $\begin{array}{l}\text { GenBank } \\
\text { accession no. }\end{array}$ & NR_042337.1 & NR_115953.1 & NR_116873.1 \\
\hline E-value & $\mathbf{0 . 0}$ & 0.0 & 0.0 \\
\hline SI & 100 & 99 & 99 \\
\hline Homology with & Bacillus altitudinis $41 \mathrm{KF} 2 \mathrm{~b}$ & $\begin{array}{c}\text { Bacillus aryabhattai } \\
\text { B8W22 }\end{array}$ & $\begin{array}{c}\text { Bacillus megaterium } \\
\text { ATCC } 1458\end{array}$ \\
\hline
\end{tabular}

SI - Similarity index $0-100 \%$ 
Based on the results (Table 1) from the PGPR traits isolates KmiJP17B089, KmiJP17B090 and KmiJP17B091 were chosen for further morphological, biochemical and genotypic characterization (Table 2). The cells were Gram positive, rod shaped, motile and spore forming when observed under phase contrast microscope. In acid production from glucose, catalase and oxidase testes, the strain was positive, differed only in the colour of the colony and nitrate reduction. PGPR mainly belong to the genera Azospirillum, Azotobacter, Arthrobacter, Bacillus, Clostridium, Enterobacter, Pseudomonas, and Serratias (Gupta et al., 2015) and among these, the species of Bacillus and Pseudomonas have perhaps been the most extensively studied (Podile and Nehra, 2006) and for their ability to produce beneficial substances (Kejela et al., 2016). Garbeva et al. (2003) concluded that a majority of soil gram positive bacteria (95\%) are members of the genus Bacillus (B. mycoides, B. pumilus, B. megaterium, B. thuringiensis, and B. firmus, etc.) similar to Paenibacillus. Bacillus sp. is the most abundant genus in rhizosphere, and due to their genetic and metabolic diversity, Bacillus sp. are well-adapted to a wide range of environmental conditions (Saxena et al., 2019).

This was confirmed in our study, using genetic analysis and PCR to identify three species of the genus Bacillus. The nucleotide sequences for a section of the $16 \mathrm{~S}$ rRNA gene from 3 selected isolates were subjected to BLAST analysis using NCBI database for identification at the genus level. All three isolates contained different nucleotide sequences for the 16S rRNA gene, indicating that they were different strains of genus Bacillus (Figure 1). KmiJP17B089 was most closely related to Bacillus altitudinis (similarity index $100 \%$ ), KmiJP17B090 to Bacillus aryabhattai (similarity index $99 \%$ ) and KmiJP17B091 to Bacillus megaterium with similarity index $99 \%$ (Table 2). The presence of the species B.megaterium was not surprising, but the other two identified species ( $B$. altiniduides and $B$ aryabhattai) are among the less frequently occurring or occurring in specific conditions with different activity. Our results indicate that the occurrence of $B$. altitudinis is not exclusive to high altitudes (Shivaji et al., 2006), and to fruits (Elbanna et al., 2014), but also occurs in rhizosphere of maize in arable soil. However, that strain play important roles not only as PGPR, but caused soft rot disease of apple and pear in Egyptian markets (Elbanna et al., 2014). According to Li et al. (2019), pot experiments verify the biocontrol effect of B. altitudinis AMCC 101304 against potato common scab. Sun et al. (2017) isolated B. altitudinis and characterized it for high IAA production, while Lu $\boldsymbol{e t}$ al. (2017) characterized it like a new potential biocontrol agent against phytopathogens fungi. Bacillus aryabhattai (strain B8W22) was initially, isolated from cryotubes used to collect air samples from the Earth's stratosphere at an altitude between 27 and $41 \mathrm{~km}$ (Shivaji et al., 2009), resulting in suggestions of a cosmic origin of this bacterium. Subsequently, the bacterium was isolated from rhizosphere soil in many parts of the world such as South Korea (Lee et al., 2012), India (Pailan et al., 2015), and Tibet (Zhang et al., 2016). The plant growth promoting activity of $B$. aryabhattai was first reported by Lee et al. (2012) because promotes the growth of Xanthium italicum. More recently, it has been shown that zinc solubilizing strains of $B$. aryabhattai improved the growth of soybean and wheat plants by increasing the mobilization and bio-fortification of zinc (Ramesh et al., 2014). ). Bacillus aryabhattai has been described by Lee $\boldsymbol{e t}$ al. (2011) like a potential plant growth promoting bacteria with high index of phosphate solubilization and the produce of indole-3acetic acids. In addition to being able to produce indolyl-3-acetic acid (Zhang $\boldsymbol{e t}$ al., 2015), Bacillus aryabhattai strain SRB02, isolated from soybean rhizosphere, was found to produce high levels of IAA, gibberellins and jasmonic acid (JA) and are found to promote the growth of soybean and alleviate oxidative stress (Park et al., 2017).

Representatives of B. megaterium are very active as PGPR because their ability to produce cytokinin (Asari $\boldsymbol{e t ~ a l . 2 0 1 7 ) , ~ t o ~ f i x ~ a t m o s p h e r i c ~ n i t r o g e n ~ ( Y o u s u f ~} \boldsymbol{e} t$ al., 2017), have been reported as phosphorus solubilizers (Panda et al., 2016), to exhibit acid and alkaline phosphatase activity (Ibarra-Galeana $\boldsymbol{e t}$ al., 2017), potassium solubilization (Verma et al., 2015), and have been reported as organic phosphorus mineralizing bacteria (Tao et al., 2008). Bacillus megaterium was reported to enhance plant growth parameters like root and shoot dry weight and seed weight under field condition in wheat (Mukhtar et al. 2017). Bacillus megaterium can suppress the growth of the phytopathogenic fungus Sclerotinia sclerotiorum (Gao et al., 2012).

The members of the genus Bacillus hold tremendous potential for biotechnological applications due to their multifarious functional attributes. Their PGP activities in soil and spore forming ability makes them an ideal candidate for developing efficient biopesticide products from technological point of view (Saxena et al., 2019). In various countries around the world, such as China, Germany, India, Italy, Japan, Switzerland, USA, there are already commercially produced and applied products based on Bacillus species $(B$. amyloliquefacines, B. cereus, B. megaterium, B. subtilis, B. thuringiensis, B. velezensis) the main mechanism of action of which is their plant growth supporting traits, mainly $\mathrm{P}$ and $\mathrm{Zn}$ solubilization, auxin production, antibiotic production and Cry 1 and Cry 2 toxins production.

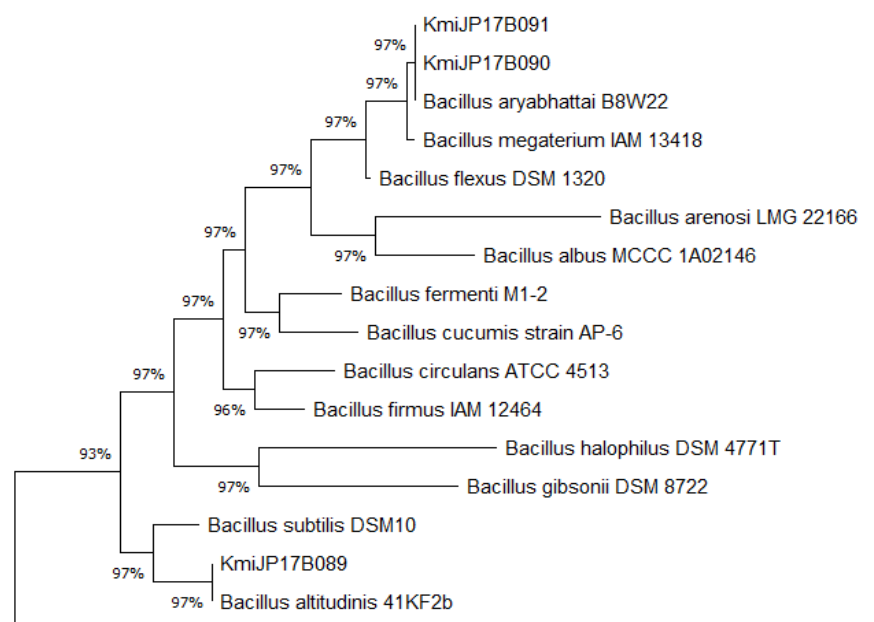

Micrococcus luteus DSM 20030T

0.050

Figure 1 Phylogenetic tree based on a comparison of the 16S rDNA sequences of Bacillus sp. isolates and some of their closest

phylogenetic relatives. The tree was created by the neighbourjoining method. The numbers on the tree indicate the percentages

of bootstrap sampling derived from 1000 replications.

\section{CONCLUSION}

This study confirmed that 11 bacterial isolates from the maize rhizosphere demonstrated at least one of the four traits of PGPR (the production of indole-3 acetic acid, siderophores, the ability to solubilize phosphates and the antifungal activity against phytopathogenic fungi) evaluated using in vitro assays.. Bacteria strains, B. altitudinis strain KmiJP17B089, B. aryabhattai strain KmiJP17B090 and B. megaterium strain KmiJP17B091 showed the best properties of PGRP and will therefore be further tested in vivo to promote the growth of maize without or with reduced use of industrial fertilizers and pesticides.

Acknowledgements: This work was supported by the National Institute of Ministry of Education, Science, Research and Sport for the Slovak republic, by the Slovak Research Grant Agency from projects KEGA 013 SPU 4/2020.

\section{REFERENCES}

AGBODJATO, N. A., NOUMAVO, P. A., BABA-MOUSSA, F., SALAMI, H A., SINA, H., SĖZAN, A., BANKOLÉ, A., ADJANOHOUN, A.,BABAMOUSSA, L. 2015. Characterization of potential plant growth promoting rhizobacteria isolated from maize (Zea mays L.) in central and northern Benin (West Africa). Applied and Environmental Soil Science, 9, 1-9. http://dx.doi.org/10.1155/2015/901656.

ALEF, K., NANNIPIERI, P. 1995. Methods in applied soil microbiology and biochemistry. London: Academic Press. 576 p.

ALI S, HAMEED S, SHAHID M, IQBAL M, LAZAROVITS G, IMRAN A. 2020. Functional characterization of potential PGPR exhibiting broad-spectrum antifungal activity. Microbiological Research, 232(126389). http://dx.doi.org/10.1016/j.micres.2019.126389.

ASARI, S., TARKOWSKÁ, D., ROLČÍK, J., NOVÁK, O., PALMERO, D. V. BEJAI, S., \& MEIJER, J. 2016. Analysis of plant growth-promoting properties of Bacillus amyloliquefaciens UCMB5113 using Arabidopsis thaliana as host plant. Planta, 245(1), 15-30. http://dx.doi.org/10.1007/s00425-016-2580-9.

ASHRAFUZZAMAN M., HOSSEN F.A., ISMAIL M.R., HOQUE M.A., ISLAM M.Z., SHAHIDULLAH S.M., MEON S. 2009. Efficiency of plant growth-promoting rhizobacteria (PGPR) for the enhancement of rice growth. $\begin{array}{llll}\text { African Journal of Biotechnology, } & 8 & \text { (7), } & 1247-1252 .\end{array}$ https://doi.org/10.5897/AJB2009.000-9198.

BARAZANI, O., FRIEDMAN, J. 1999. Is IAA the major root growth factor secreted from plant-growth-mediating bacteria? Journal of Chemical Ecology, 25(10), 2397-2406. http://dx.doi.org/10.1023/a:1020890311499

BERRAQUERO, F.R., BAYA, A.M., CORMENZANA, A.R. 1976 Establishment of indices for the study of phosphate solubilization by soil bacteria. Ars Pharmacéutica, 17, 399-406.

BENEDUZI, A., AMBROSINI, A., PASSAGLIA, L. 2012. Plant growthpromoting rhizobacteria (PGPR): their potential as antagonists and biocontrol agents. Genetics and molecular biology, 35 (4 suppl.) 1044-1051. https://www.scielo.br/pdf/gmb/v35n4s1/20.pdf. 
CHAROUSOVÁ, I., MEDO, J., HALENÁROVÁ, E., MAKOVÁ, J., JAVOREKOVÁ, S. 2016. Effect of fertilization on biological activity of community of soil streptomycetes. Journal of Central European Agriculture, 17(4), 1134-1148. http://dx.doi.org/10.5513/JCEA01/17.4.1822.

DE LA TORRE-RUIZ N., RUIZ-VALDIVIEZO V.M., RINCON-MOLINA C.I., RODRIGUEZ-MENDIOLA M., ARIAS-CASTRO C., GUTIERREZ-MICELI, F.A., PALOMEQUE-DOMINGUEZ H., RINCON-ROSALES R. 2016. Effect of plant growth-promoting bacteria on the growth and fructan production of Agave americana L. Brazilian Journal of Microbiology 47 (3), 587-596. https://10.1016/j.bjm.2016.04.010.

ELBANNA, K., ELNAGGAR, S., BAKEER, A.2014. Characterization of Bacillus altitudinisas a new causative agent of bacterial soft rot. Journal of Phytopathology, 162(11-12), 712-722. http://dx.doi.org/10.1111/jph.12250.

GARBEVA, P., VAN VEEN, J.A., VAN ELSAS, J.D., 2003. Predominan Bacillus spp. in agricultural soil under different management regimes detected via PCR-DGGE. Microbial Ecology, 45(3), 302-316. http://dx.doi.org/10.1007/s00248-002-2034-8.

GAO, X., HAN, Q., CHEN, Y., QIN, H., HUANG, L., KANG, Z. 2012. Biological control of oilseed rape Sclerotinia stem rot by Bacillus subtilis strain Em7. Biocontrol science and technology, 2014, 24(1), 39-52. http://dx.doi.org/10.1080/09583157.2013.844223.

GORDON, S.A.; WEBER, R.P. 1951. Colorimetric estimation of indoleacetic acid. Plant physiology, 26 (1), 192-195.

GROBELAK, A., NAPORA, A., KACPRZAK, M. 2015. Using plant growthpromoting rhizobacteria (PGPR) to improve plant growth. Ecological Engineering, 84, 22-28. http://dx.doi.org/10.1016/j.ecoleng.2015.07.019. GUPTA, R., SINGAL, R., SHANKAR, A., KUHAD, R.C., SAXENA, R.K. 1994. A modified plate assay for screening phosphate solubilizing microorganisms. The Journal of General and Applied Microbiology, 40(3), 25560. http://dx.doi.org/10.2323/jgam.40.255.

GUPTA, G., PARIHAR, S.S., AHIRWAR, N.K., SNEHI, S.K., SINGH, V. 2015 Plant growth promoting rhizobacteria (PGPR): current and future prospects for development of sustainable agriculture. Journal of Microbial and Biochemical Technology, 2015, 7(2), 96-102. http://dx.doi.org/10.4172/1948-5948.1000188. HALENÁROVÁ, E., MEDO, J., KOVÁCSOVÁ, S., CHAROUSOVÁ, I, MAKOVÁ, J., ELBL, J., ZÁHORA, J.,JAVOREKOVÁ, S. 2016. Effect of vermicompost on changes in the bacterial community in maize rhizosphere Journal of Central European Agriculture, 17(4), 1033-1049. http://dx.doi.org/10.5513/jcea01/17.4.1808.

HILTNER, L. 1904. Uber neuere Erfahrungen und Probleme auf dem Gebiete der Bodenbakteriologie unter besonderden berucksichtigung und Brache. Arb.

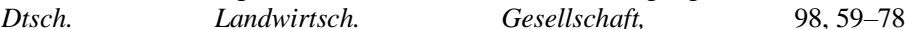
https://ci.nii.ac.jp/naid/10014758256/en/

IBARRA-GALEANA, J.A., CASTRO-MARTINEZ, C., FIERRO-CORONADO R.A., ARMENTA-BOJORQUEZ, A.D. AND MALDONADO-MENDOZA, I.E. 2017. Characterization of phosphate-solubilizing bacteria exhibiting the potential for growth promotion and phosphorus nutrition improvement in maize (Zea mays L.) in calcareous soils of Sinaloa, Mexico. Annals of Microbiology, 67(12), 801811. http://dx.doi.org/10.1007/s13213-017-1308-9.

JAVOREKOVÁ, S., KOVÁCSOVÁ, S., MEDO, J., MAKOVÁ, J., PETROVÁ, J., HLEBA, L., KOŠŤÁLOVÁ, D., CINKOCKI, R. 2019. Soil amended with organic fertilizers as a source of actinomycetes with high potential as biocontrol agents. Journal of Microbiology, Biotechnology and Food Sciences, 8(6), 13521359. http://dx.doi.org/10.15414/jmbfs.2019.8.6.1352-1359.

KARNWAL, A. 2017. Isolation and identification of plant growth promoting rhizobacteria from maize (Zea mays L.) rhizosphere and their plant growth promoting effect on rice (Oryza sativa L.). Journal of Plant Protection Research, 57(2), 144-151. https://doi.org/10.1515/jppr-2017-0020.

KAUR, A., DEVI, S.R., VYAS, P. 2018. Stress-tolerant antagonistic plant growth-promoting rhizobacteria from Zea mays. Journal of Plant Protection Research, 58(2), 115-123. https://doi.org/10.24425/119127.

KEJELA T., THAKKAR V.R., THAKOR P. 2016. Bacillus species (BT42) isolated from Coff ea arabica L. rhizosphere antagonizes Colletotrichum gloeosporioides and Fusarium oxysporum and also exhibits multiple plant growth promoting activity. BMC Microbiology, 16 (277). http://dx.doi.org/10.1186/s12866-016-0897-y.

KHAN, A., SINGH, P., SRIVASTAVA, A. 2018. Synthesis, nature and utility of universal iron chelator-Siderophore: A review. Microbiological research, 212 213, 103-111. http://dx.doi.org/10.1016/j.micres.2017.10.012.

KUMAR, V., NARULA, N. 1999. Solubilization of inorganic phosphates and growth emergence of wheat as affected by Azotobacter chroococcum mutants. Biology and Fertility of Soils, 28(3), 301-305. http://dx.doi.org/10.1007/s003740050497.

LANE, D.J. 1991. 16S/23S rRNA sequencing. In: STACKEBRANDT, E.; GOODFELLOW, M., (Eds.). Nucleic acid techniques in bacterial systematics. New York: John Wiley and Sons, 115-175.

LEE, S., KA, J.O., SONG, H.G. 2012. Growth promotion of Xanthium italicum by application of rhizobacterial isolates of Bacillus aryabhattai in microcosm soil. The Journal of Microbiology, 50(1), 45-49. http://dx.doi.org/10.1007/s12275$\underline{012-1415-\mathrm{Z}}$
LI, B., WANG,B., PAN P, LI, P., QI, Z., ZHANG, Q., SHI, C., HAO, W. ZHOU, B., LIN, R. 2019. Bacillus altitudinis strain AMCC 101304: a novel potential biocontrol agent for potato common scab. Biocontrol science and technology, 29(10),

1009-1022 http://dx.doi.org/10.1080/09583157.2019.1641791.

LU, X., ZHOU, D., CHEN, X., ZHANG, J., HUANG, H., WEI, L. 2017. Isolation and characterization of Bacillus altitudinis JSCX-1 as a new potential biocontrol agent against Phytophthora sojae in soybean [Glycine max (L.) Merr.]. Plant and Soil, 2017, 416(1-2), 53-66. http://dx.doi.org/10.1007/s11104017-3195-Z.

MARRA, L. M., OLIVEIRA, S. M. DE, SOARES, C. R. F. S., MOREIRA, F. M de S. 2011. Solubilisation of inorganic phosphates by inoculant strains from tropical legumes. Scientia Agricola http://dx.doi.org/10.1590/s0103-90162011000500015.

MASALHA, J., KOSEGARTEN, H., ELMACI, Ö., MENGEL, K. 2000. The central role of microbial activity for iron acquisition in maize and sunflower Biology and Fertility of Soils., 30(5-6), 433-439. http://dx.doi.org/10.1007/s003740050021.

MELNICHUK, T. EGOVVTSEVA, A., ABDURASHYTOV, S., KAMENEVA, I. YAKUBOVSKAJA, A., RADCHENKO, A., GANOTSKAYA, T. RADCHENKO, L. 2019. Associative to triticum aestivum L. bacteria as a source of strains for biotechnology of the rhizosphere. Journal of Microbiology, Biotechnology, and Food Sciences, 8(5) 1194-1197. https://dx.doi.org./10.15414/jmbfs.2019.8.5.1194-1197.

MENDES, R., GARBEVA, P., RAAIJMAKERS, J.M. 2013. The rhizosphere microbiome: significance of plant beneficial, plant pathogenic, and human pathogenic microorganisms. FEMS microbiology reviews, 37(5), 634-663. http://dx.doi.org/10.1111/1574-6976.12028.

MRKOVACKI, N., DJALOVIC, I., JOSIC, D., BJELIC, D., BRDAR JOKANOVIC, M. 2016. The effect of PGPR strains on microbial abundance in maize rhizosphere in field conditions. Ratarstvo i Povrtarstvo, 53(1), 15-19. http://dx.doi.org/10.5937/ratpov53-8224.

MUKHTAR, S., SHAHID, I., MEHNAZ, S., MALIK, K.A. 2017. Assessment of two carrier materials for phosphate solubilizing biofertilizers and their effect on growth of wheat (Triticum aestivum L.). Microbiological Research, 205, 107117. http://dx.doi.org/10.1016/j.micres.2017.08.011.

NEILANDS, J.B.; LEONG, S.A. 1986. Siderophores in relation to plant growth and disease. Annual Review of Plant Physiology, 37(1), 187-208. http://dx.doi.org/10.1146/annurev.pp.37.060186.001155.

PANDA, B., RAHMAN, H., PANDA, J. 2016. Phosphate solubilizing bacteria from the acidic soils of Eastern Himalayan region and their antagonistic effect on fungal pathogens. Rhizosphere, 2, 62-71. http://dx.doi.org/10.1016/j.rhisph.2016.08.001

PARK, Y.G., MUN, B.G., KANG, S.M., HUSSAIN, A., SHAHZAD, R., SEO, CH.W., KIM, AH.Y., LEE S.U., OH, K.Y., Lee D.Y., LEE, I.J., YUN, B.W 2017. Bacillus aryabhattai SRB02 tolerates oxidative and nitrosative stress and promotes the growth of soybean by modulating the production of phytohormones. Plos One.12(3), e0173203. http://dx.doi.org/10.1371/journal.pone.0173203.

PAILAN, S., GUPTA, D., APTE, S., KRISHNAMURTHI, S., SAHA, P. 2015. Degradation of organophosphate insecticide by a novel Bacillus aryabhattai strain SanPS1, isolated from soil of agricultural field in Burdwan, West Bengal, India. International Biodeterioration \& Biodegradation 10(3), 191-195. http://dx.doi.org/10.1016/j.ibiod.2015.05.006.

PODILE, A.R., KISHORE, G.K.2006. Plant growth-promoting rhizobacteria Plant-Associated Bacteria. Kluwer Academic Publishers, 195-230. http://dx.doi.org/10.1007/1-4020-4538-7_6.

PRAVEEN KUMAR, G., MIR HASSAN AHMED, S.K., DESAI, S., LEO, DANIEL AMALRAJ, E., RASUL, A. 2014. In vitro screening for abiotic stress tolerance in potent biocontrol and plant growth promoting strains of Pseudomonas and Bacillus spp. International Journal of Bacteriology, 6, 1-6. http://dx.doi.org/10.1155/2014/195946.

PUENTE, M. E., LI, C. Y., BASHAN, Y. 2004. Microbial populations and activities in the rhizoplane of rock-weathering desert plants. II. Growth promotion of cactus seedlings. Plant Biology, 6(5), 643-650. http://dx.doi.org/10.1055/s-2004-821101.

RAAIJMAKERS, J.M., PAULITZ, T.C., STEINBERG, C., ALABOUVETTE, C., MOËNNE-LOCCOZ Y.. 2009. The rhizosphere: a playground and battlefield for soilborne pathogens and beneficial microorganisms. Plant and soil, 2009 , 321 (1-2), 341-361. http://dx.doi.org/10.1007/s11104-008-9568-6.

RAMESH, A., SHARMA, S.K., SHARMA, M.P., YADAV, N., JOSHI, O.P. 2014. Inoculation of zinc solubilizing Bacillus aryabhattai strains for improved growth, mobilization and biofortification of zinc in soybean and wheat cultivated in Vertisols of central India. Applied Soil Ecology, 2014 (73), 87-96. http://dx.doi.org/10.1016/j.apsoil.2013.08.009.

RIBEIRO, C.M., CARDOSO, E.J.B.N. 2012. Isolation, selection and characterization of root-associated growth promoting bacteria in brazil pine (Araucaria angustifolia). Microbiological Research. 167(2), 69-78. http://dx.doi.org/10.1016/j.micres.2011.03.003. 
SAITOU, N., NEI, M. 1987. The neighbor-joining method: a new method for reconstructing phylogenetic trees. Molecular Biology and Evolution, 4(4), 406425. https://doi.org/10.1093/oxfordjournals.molbev.a040454.

SANTOS, S., NETO, I.F.F., MACHADO, M.D., SOARES, H.M.V.M., SOARES, EV. 2014. Siderophore production by Bacillus megaterium: effect of growth phase and cultural conditions. Applied Biochemistry and Biotechnology, 172(1), 549-560. http://dx.doi.org/10.1007/s12010-013-0562-y.

SAXENA, A.K., KUMAR, M., CHAKDAR, H., ANUROOPA, N., BAGYARAJ., D.J. 2019. Bacillus species in soil as a natural resource for plant health and nutrition. Journal of Applied Microbiology, 128(6), 1583-1594. http://dx.doi.org/10.1111/jam.14506.

SGROY, V., CASSAN, F. MASCIARELLI, O., DEL PAPA, M.F., LAGARES, A., LUNAET, V. 2009. Isolation and characterization of endophytic plan growth-promoting (PGPB) or stress homeostasis-regulating (PSHB) bacteria associated to the halophyte Prosopis strombulifera. Applied microbiology and Biotechnology, 2009, 85(2), 371-381. https://doi.org/10.1007/s00253-009-2116-

SHAHID, M., HAMEED, S., IMRAN, A., ALI, S., VAN ELSAS, J.D.2012. Root colonization and growth promotion of sunflower (Helianthus annuus L.) by phosphate solubilizing Enterobacter sp. Fs-11. World Journal of Microbiology and Biotechnology, 28(8), 2749-2758. http://dx.doi.org/10.1007/s11274-0121086-2.

SHIVAJI, S., CHATURVEDI, P., SURESH, K., REDDY, S., DUTT, B., WAINWRIGHT, M., NARLIKAR, V., BHARGAVA, M. 2006. Bacillus aerius sp. nov., Bacillus aerophilus sp. nov., Bacillus stratosphericus sp. nov. and Bacillus altitudinis sp. nov., isolated from cryogenic tubes used for collecting air samples from high altitudes. Journal of Systematic and Evolutionary Microbiology, 56(7), 1465-1473. http://dx.doi.org/10.1099/ijs.0.64029-0.

SHIVAJI S, CHATURVEDI P, BEGUM Z, PINDI PK, MANORAMA R, PADMANABAN DA, SHOUCHE, Y. S., PAWAR, S., VAISHAMPAYAN, P., DUTT, C. B. S., DATTA, G. N., MANCHANDA, R. K., RAO, U. R., BHARGAVA, P. M., NARLIKAR, J. V. 2009. Janibacter hoylei sp. nov., Bacillus isronensis sp. nov. and Bacillus aryabhattai sp. nov., isolated from cryotubes used for collecting air from the upper atmosphere. International Journal of Systematic and Evolutionary Microbiology, 59(12), 2977-2986. https://doi.org/10.1099/ijs.0.002527-0.

SCHWYN, B., NEILANDS, J. B. 1987. Universal chemical assay for the detection and determination of siderophores. Analytical Biochemistry, 160(1), 4756. http://dx.doi.org/10.1016/0003-2697(87)90612-9.

SILINI-CHERIF, H., SILINI, A., GHOUL, M., YADAV, S. 2012 Isolation and characterization of plant growth promoting traits of a rhizobacteria: Pantoea agglomerans lma2. Pakistan Journal of Biological Sciences, 15(6), 267-276. http://dx.doi.org/10.3923/pjbs.2012.267.276.

SUN, Z., LIU, K., ZHANG, J., ZHANG, Y., XU, K., YU, D., WANG, J., HU, L. CHEN, L., LI, CH. 2017. AA producing Bacillus altitudinis alleviates iron stress in Triticum aestivum L. seedling by both bioleaching of iron and up-regulation of genes encoding ferritins. Plant and Soil, 419(1-2), 1-11. http://dx.doi.org/10.1007/s11104-017-3218-9.

TAMURA, K., PETERSON, D., PETERSON, N., STECHER, G., NEI, M. KUMAR, S. 2011. MEGA5: molecular evolutionary genetics analysis using maximum likelihood, evolutionary distance, and maximum parsimony methods. Molecular Biology and Evolution, 28(10), 2731-2739. http://dx.doi.org/10.1093/molbev/msr121.

TIAN, F., DING, Y., ZHU, H., YAO, L., DU, B. 2009. Genetic diversity of siderophore-producing bacteria of tobacco rhizosphere. Brazilian Journal of Microbiology, 40(2), 276-284. http://dx.doi.org/10.1590/s1517$\underline{83822009000200013 .}$

TAO, G-C., TIAN, S-J., CAI, M-Y., XIE, G-H.2008. Phosphate-solubilizing and -mineralizing abilities of bacteria isolated from soils. Pedosphere, 18(4), 51523. http://dx.doi.org/10.1016/s1002-0160(08)60042-9.

VACHERON, J., DESBROSSES, G., BOUFFAUD, M-L., TOURAINE, B., MOËNNE-LOCCOZ, Y., MULLER, D., LEGENDRE, L., WISNIEWSKI-DYÉ, F., PRIGENT-COMBARET, C. 2013. Plant growth-promoting rhizobacteria and root system functioning. Frontiers in Plant Science, 4(356). http://dx.doi.org/10.3389/fpls.2013.00356.

VERMA, P., YADAV, A.N., KHANNAM, K.S., PANJIAR, N., KUMAR, S., SAXENA, A.K., SUMAN, A. 2015. Assessment of genetic diversity and plan growth promoting attributes of psychrotolerant bacteria allied with wheat (Triticum aestivum) from the northern hills zone of India. Annals of Microbiology, 65(4), 1885-1899. http://dx.doi.org/10.1007/s13213-014-1027-4.

VURUKONDA, S.S.K.P., VARDHARAJULA, S., SHRIVASTAVA, M., SKZ, A. 2016. Enhancement of drought stress tolerance in crops by plant growth promoting rhizobacteria. Microbiological research, 184, 13-24. http://dx.doi.org/10.1016/j.micres.2015.12.003.

YADAV, A.N., VERMA, P., SINGH, B., CHAUHAN, V.S., SUMAN, A. SAXENA, A.K. 2017. Plant growth promoting bacteria: biodiversity and multifunctional attributes for sustainable agriculture. Advances in Biotechnology and Microbiology, 5(5), 1-16. http://dx.doi.org/10.19080/aibm.2017.05.5556671. YOUSUF, J., THAJUDEEN, J., RAHIMAN, M., KRISHNANKUTTY, S.P., ALIKUNJ, A. A., ABDULLA, M.H. 2017. Nitrogen fixing potential of various heterotrophic Bacillus strains from a tropical estuary and adjacent coastal regions. Journal of Basic Microbiology, 57(11), $922-932$ http://dx.doi.org/10.1002/jobm.201700072.

ZHEN, S., KAIQI, L., CHANGXU, L., JIAN, Y., RUICHENG, J., XUNLI, L. 2011. Isolation and characterization of a potential biocontrol Brevibacillus laterosporus. African Journal of Microbiology Research, 5(18), 2675-2681. http://dx.doi.org/10.5897/ajmr11.335.

ZHANG, W., HE, L., WANG, Q., SHENG, X. 2016. Inoculation with endophytic Bacillus megaterium 1 Y 31 increases Mn accumulation and induces the growth and energy metabolism-related differentially-expressed proteome in Mn hyperaccumulator hybrid pennisetum. Journal of Hazardous Materials, 300 , 513-521. http://dx.doi.org/10.1016/j.jhazmat.2015.07.049. 